\title{
Determination of Etimicin in Rat Plasma using 9-Fluorenylmethyl Chloroformate Precolumn Derivatization by HPLC with Fluorescence Detection
}

\author{
Xiaojuan Chang and Zhengping Yu*
}

\author{
Key Laboratory of Electromagnetic Radiation Protection, Department of Occupational Health, Faculty of \\ Preventive Medicine, Third Military Medical University, Chongqing 400038, People's Republic of China
}

\begin{abstract}
Um método novo e sensível foi desenvolvido para a determinação de etimicina (ETM) utilizando pré-coluna de derivatização (PCD) com 9-fluorenilmetilcloroformiato (FMOC-Cl) por separação de fase reversa e subsequente detecção por fluorescência. As condições PCD foram todas otimizadas para o menor limite de detecção. A separação cromatográfica foi efetuada em uma coluna Agilent XDB-C 8 a $25^{\circ} \mathrm{C}$, velocidade de fluxo de $1,0 \mathrm{~mL} \mathrm{~min}^{-1}$ e fase móvel acetonitrila/água $(87: 13, v / v)$. O derivativo etimicina-FMOC-Cl foi monitorado por detecção de fluorescência a $\lambda_{\text {excitação }} 265 \mathrm{~nm}$ e $\lambda_{\text {emissão }} 315 \mathrm{~nm}$. Neomicina, um composto de estrutura similar ao ETM foi usado como padrão interno. A avaliação estatística do método foi examinada, mostrando-se preciso e exato com um intervalo de linearidade de $0,038-9,69 \mu \mathrm{gL}^{-1}(\mathrm{r}>0,9994)$. Os estudos de precisão intra- e inter-dia mostraram boa reprodutividade com desvio padrão médio (R.S.D.) menor que $5 \%$, e recuperação de 97,80-100,09 \% (n = 3). O limite de detecção (LOD) e o limite inferior de quantificação (LLOQ) em plasma foram 0,01 e $0,02 \mu \mathrm{g} \mathrm{mL}{ }^{-1}$, respectivamente. Um volume de $50 \mu \mathrm{L}$ de plasma foi suficiente para detecção de etimicina. O método estabelecido fornece um método bionalítico confiável para a farmacocinética de etimicina em plasma de rato.
\end{abstract}

A new and sensitive method was developed for the determination of the etimicin (ETM) using precolumn derivatization (PCD) with 9-fluorenylmethyl chloroformate (FMOC-Cl) by a reversed phase separation and subsequent fluorescence detection. The PCD conditions were fully optimized towards the lowest limit of detection. The chromatographic separation was carried out on an Agilent XDB-C8 column at $25^{\circ} \mathrm{C}$ using a constant flow rate of $1.0 \mathrm{~mL} \mathrm{~min}^{-1}$ and mobile phase of acetonitrile/water $(87: 13, \mathrm{v} / \mathrm{v})$. The etimicin-FMOC-Cl derivative was monitored by fluorescent detection at $\lambda_{\text {excitation }} 265 \mathrm{~nm}$ and $\lambda_{\text {emission }} 315 \mathrm{~nm}$. Neomycin (NMC), a similar base structure compound with ETM, was used as an internal standard. The statistical evaluation of the method was examined and the method was found to be precise and accurate with a linearity range of $0.038-9.69 \mu \mathrm{g} \mathrm{mL}^{-1}$ $(\mathrm{r}>0.9994)$. The intra- and inter-day precision studies showed good reproducibility with relative standard deviation (R.S.D.) less than 5\%, and the relative recovery was $97.80-100.09 \%(\mathrm{n}=3)$. The limit of detection (LOD) and lower limit of quantification (LLOQ) in plasma were 0.01 and $0.02 \mu \mathrm{g} \mathrm{mL} \mathrm{mL}^{-1}$, respectively. A volume of $50 \mu \mathrm{L}$ of plasma was sufficient for the determination of etimicin. The established method provides a reliable bioanalytical method to carry out etimicin pharmacokinetics in rat plasma.

Keywords: high-performance liquid chromatography, 9-fluorenylmethyl chloroformate, derivatization, etimicin, pharmacokinetic

\section{Introduction}

Etimicin (ETM) is mainly used as the sulfate and the fourth-generation aminoglycoside antibiotics, which is all water soluble aminoglycoside derived from gentamycin $\mathrm{C}_{1 \mathrm{a}}$ (Figure 1). ${ }^{1}$ It is widely used in human and veterinary medicine against both Gram-positive and Gram-negative

*e-mail: yuzhping@yahoo.cn bacterial infections, including resistant strains to other aminoglycosides..$^{2-5}$ ETM has maintained and strengthened the advantages of former aminoglycoside antibiotics and reduced its toxicity. The oto- and nephro-toxicity of ETM are substantially lower than those of other aminoglycisides antibiotics, such as netilmicin. ${ }^{3,4}$ Otherwise, ETM also causes damage to the kidneys and cranial nerves, so it is significant for quantitatively determination of the drug in the pharmaceutical preparations and in body. As can 
be seen, like many other aminoglycosides, ETM lacks a suitable chromophore for UV or fluorimetric detection. But a wide variety of methods for the bioanalysis of aminoglycoside antibiotics in biological samples has been investigated over the years, including resonance Rayleigh scattering spectra, ${ }^{6}$ microbiological assay, ${ }^{7}$ immunoassays, ${ }^{8,9}$ capillary electrophoresis, ${ }^{10,11}$ thin layer chromatography, ${ }^{12}$ gas-liquid chromatography, ${ }^{13}$ and high-performance liquid chromatography (HPLC) with detection of evaporative light scattering, ${ }^{14,15}$ pulsed electrochemical ${ }^{16-19}$ and mass spectrometry, ${ }^{20-22}$ highperformance liquid chromatography with precolumn ${ }^{23-31}$ and post-column derivatization ${ }^{32}$ methods. ETM has a structure of aminoglycoside and the methods mentioned above should also be applicable for it. Among these methods, microbiological assay is not able to distinguish between the main components and the impurities in the drug. Reversed-phase liquid chromatography with precolumn derivatization with $o$-phthalaldehyde (OPA ${ }^{25}$ and with 1-fluoro-2,4-dinitrobenzene, ${ }^{28}$ in which derivatized etimicin was used as internal standard, has been described. However, no liquid chromatograph method has been described to analyze etimicin sulfate as a drug substance and to study the research on the pharmacokinetics. The lower limit of quantification (LLOQ) of vertilmicin was $0.5 \mu \mathrm{g} \mathrm{mL} \mathrm{L}^{-1}$ for the determination in rat serum and not referred to LLOQ of ETM. Evaporative light-scattering detection (ELSD) $)^{15}$ is prescribed for the determination of ETM content, LC-pulsed amperometric detection (PAD) $)^{33}$ is also prescribed in the determination of ETM purity and content. Liquid chromatography with pulsed electrochemical detection $^{34}$ also determined ETM content, being not able to determine possible pharmacokinetics in the body, either. Moreover, a volatile mobile phase is required for ELSD
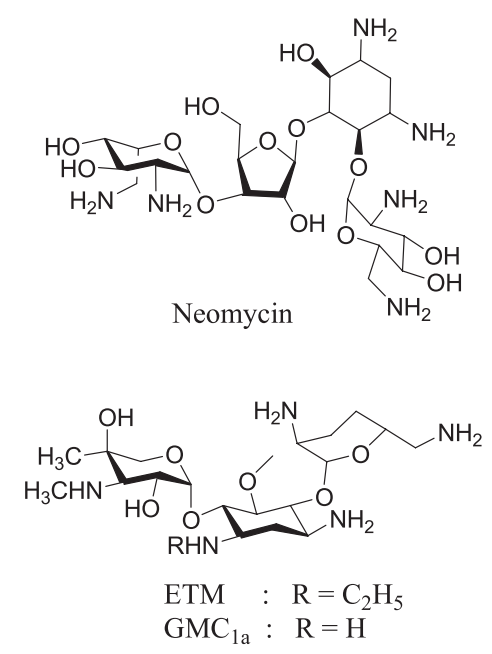

Figure 1. The structure of neomycin (NMC), etimicin (ETM) and gentamycin $\mathrm{C}_{1 \mathrm{a}}\left(\mathrm{GMC}_{\mathrm{aa}}\right)$. detection, which is low sensitive in detection. Up untill now, the research on the pharmacokinetics of ETM in the body by HPLC with fluorescence detection has not been reported yet.

In the present study, a simple, stable, sensitive and validated HPLC method using fluorescence detection for the determination of ETM in plasma post-inhalation is proposed. The precolumn derivatization (PCD) was made with 9-fluorenylmethyl chloroformate (FMOC-Cl) that reacts with the fourth-generation groups of ETM under mild conditions to form a highly fluorescent and stable derivative. The method was also successfully applied for a pharmacokinetic study.

\section{Experimental}

\section{Reagents and chemicals}

ETM and neomycin (NMC used as an internal standard) were purchased from Sigma Chemical (MO, USA). The 9-fluorenylmethyl chloroformate (FMOC-Cl, 98\%) was purchased from J\&K Chemical Ltd. (Beijing, China). All solvents used in this study were of HPLC grade and purchased from Kermel Company (Tianjin, China). Potassium chloride, potassium hydroxide and boric acid were purchased from Chongqing Chemical Reagent Co. Water was glass-double distilled and further purified for HPLC with a Millipore SZ-93 system (Shanghai Yarong Biochemical apparatus Co.).

\section{Apparatus}

The chromatographic system (Agilent 1100 series HPLC) (Agilent Technologies, CA, USA) consisted of an Agilent G1311A QuatPump fitted with a G1322A Degasser and a column oven. The detector used in the experiment was an Agilent G1321A FLD. The separation was performed on an Agilent XDB-C8 (particle size $5 \mu \mathrm{m}$, $150 \times 4.6 \mathrm{~mm}$ i.d.) column (Agilent Technologies, CA, USA) with a mixture of water- acetonitrile $(13: 87, \mathrm{v} / \mathrm{v})$ as mobile phase. The mobile phase was filtered through a $0.22 \mu \mathrm{m}$ pore size membrane filter before use. The column oven temperature was set at $25{ }^{\circ} \mathrm{C}$ and the flow rate was $1.0 \mathrm{~mL} \mathrm{~min}^{-1}$. Fluorescence detection wavelengths were set at $\lambda_{\text {excitation }} 265 \mathrm{~nm}$ and $\lambda_{\text {emission }} 315 \mathrm{~nm}$. The $\mathrm{pH}$ value of solution was measured using a Mettler Toledo Delta $320 \mathrm{~m}$ (Mettler-Toledo, Shanghai, China).

\section{Solutions}

The derivatization reagent consisted of $10 \mathrm{mmoL} \mathrm{L}^{-1}$ FMOC-Cl in acetonitrile. Borate buffer solution 
(0.2 mmoL $\left.\mathrm{L}^{-1}\right)$ was firstly prepared by dissolving $1.25 \mathrm{~g}$ boric acid and $1.50 \mathrm{~g}$ potassium chloride in $100 \mathrm{~mL}$ water and then adjusted the $\mathrm{pH}$ from 6.5 to 8.5 with $0.2 \mathrm{mmoL} \mathrm{L}^{-1}$ potassium hydroxide solution. Etimicin and neomycin were dissolved respectively in ultrapure water as stock standard solution $\left(1 \mathrm{~g} \mathrm{~L}^{-1}\right)$ and $\left(0.54 \mathrm{~g} \mathrm{~L}^{-1}\right)$, respectively. These solutions were all stored at $4{ }^{\circ} \mathrm{C}$ before use.

\section{Sample preparation and precolumn derivatization}

A volume of $50 \mu \mathrm{L}$ of rat plasma was mixed with a $25 \mu \mathrm{L}$ of internal standard solution $\left(0.216 \mathrm{mg} \mathrm{mL}^{-1} \mathrm{NMC}\right)$ and $150 \mu \mathrm{L}$ of acetonitrile. The solution was vortex-mixed for $50 \mathrm{~s}$ and centrifuged for $15 \mathrm{~min}$ at $12000 \times \mathrm{g}$. An aliquot of $50 \mu \mathrm{L}$ of the clear supernatant was adjusted to optimal $\mathrm{pH}$ by the addition of $50 \mu \mathrm{L}$ of borate buffer $\left(0.2 \mathrm{mmoL} \mathrm{L}^{-1}\right.$ in water, $\mathrm{pH} 7.3$ ) and derivatized with $50 \mu \mathrm{L}$ FMOC-Cl (10.05 $\mu \mathrm{g} \mathrm{mL}^{-1}$ in acetonitrile) and then brief mixing for $10 \mathrm{~s}$ on a vortex mixer. The samples were kept at ambient temperature for $35 \mathrm{~min}$. A volume of $20 \mu \mathrm{L}$ of the reaction mixture was injected into the HPLC system.

\section{Method validation}

\section{Assay specificity}

The specificity of the method was demonstrated by comparing chromatograms of five independent plasma samples from rats, each as a blank and a spiked sample.

\section{Calibration and calculation procedure}

Standard calibration curve was constructed by spiking drug free plasma with a known amount of ETM in the concentration range of $0.038-9.69 \mu \mathrm{g} \mathrm{mL}^{-1}$. The plasma standards were also used to determine the intra- and inter-day precision and accuracy of the method. The concentration of ETM was calculated through the ratio between the peak areas of ETM and internal standard. Calibration curve was obtained by plotting the peak area ratios on the abscissa and the respective drug concentrations ratios between ETM and internal standard on the ordinate. The unknown samples concentrations were calculated from the linear regression equation of the peak area ratio against concentrations ratio of the calibration curve.

\section{Precision and accuracy of the assay}

The precision was defined as the relative standard deviation (R.S.D.) calculated using quality control samples $(n=5)$. The accuracy was defined as the relative error $(R E)$ of the mean of QC samples $(n=5)$ from the theoretical concentrations. In order to evaluate the intra-day precision and accuracy, five replicate samples of each concentration of QC samples were analyzed in the same day. The inter-day validation was evaluated on the QC samples of different days. Intra- and inter-day assays were assessed using five spiked serum samples at each concentrations of $0.15,3.64$ and $7.27 \mu \mathrm{g} \mathrm{mL} \mathrm{L}^{-1}$.

\section{Relative recovery and analyte stability}

The relative recoveries of ETM and neomycin from plasma were determined in the following text. Five samples for each concentration were processed as described previously. Relative recovery was obtained by comparing the peak area of ETM of the extracted samples with which calculated from the calibration curve.

The stability of ETM in rat plasma was determined at short-term stored in refrigerator $\left(4{ }^{\circ} \mathrm{C}\right)$ for $0-24 \mathrm{~h}$, long-term storage at $-20^{\circ} \mathrm{C}$ for $1,3,5,8$ and 10 days and freeze-thaw cycles for two cycles, respectively. To estimate the stability of derivatized solutions, the derivatized ETM and the internal standard solutions were assayed over a period of $24 \mathrm{~h}$.

\section{Application of the method}

The female rats were fasted overnight with a free access to water for at least $12 \mathrm{~h}$ before the experiment. The average weight of those rats was $164.2 \mathrm{~g}$. The drug was administered to the rats following the clinical administration. The established analytical method was used to investigate the profile of ETM, after intravenous injection of $30 \mathrm{mg} \mathrm{kg}^{-1}$ ETM to five Wistar rats via the tail vein. After administration, $0.2 \mathrm{~mL}$ of blood was collected at the time intervals of $0,0.25,0.5,0.75,1,1.5,2,4,6,8$ and $12 \mathrm{~h}$ post-dosing. The plasma was immediately separated by centrifugation at $3000 \times \mathrm{g}$ for $10 \mathrm{~min}$ and stored at $-20^{\circ} \mathrm{C}$ until analyzed. The plasma concentration-time curves of ETM in rats were plotted.

\section{Results and Discussion}

\section{Chromatographic separation and specificity}

The typical chromatograms of derivatized products of ETM and the internal standard are shown in Figure 2. The peaks for their derivatized products were not interfered by endogenous substances. The retention times for derivatized products of the internal standard and ETM were approximately 5.5 and $9.9 \mathrm{~min}$, respectively. The specificity of fluorometric detection after use of FMOC depends on two factors. First, the emission wavelength of ETM-FMOC is specific and no endogenous interference has been detected compared with drug-free plasma. Second, 

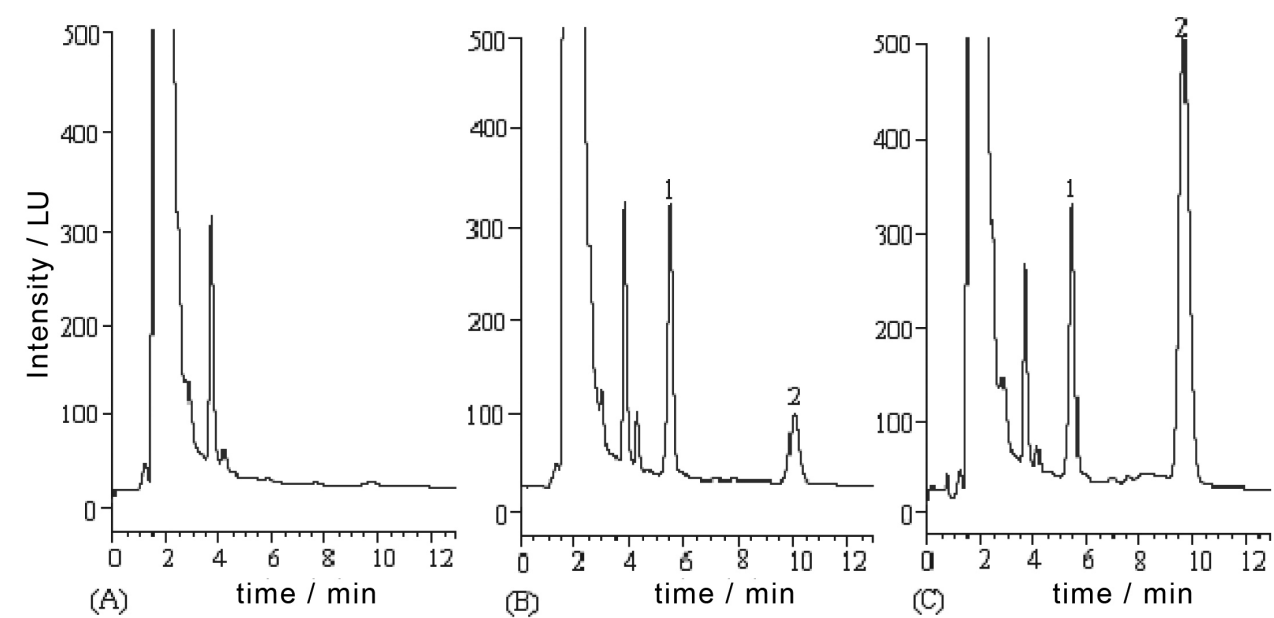

Figure 2. Representative chromatograms of the FMOC-Cl-derivatized products: (A) A blank rat plasma sample, (B) a blank rat plasma sample spiked with ETM (concentration at $0.303 \mu \mathrm{g} \mathrm{mL}^{-1}$ ) and the internal standard (concentration at $3.27 \mu \mathrm{g} \mathrm{mL}^{-1}$ ) and $(\mathrm{C}$ ) a rat plasma sample $2.0 \mathrm{~h}$ after intravenous administration of $30 \mathrm{mg} \mathrm{kg}^{-1}$ ETM. Peaks 1 and 2 refer to the FMOC-Cl-derivatized products of the internal standard and ETM, respectively.
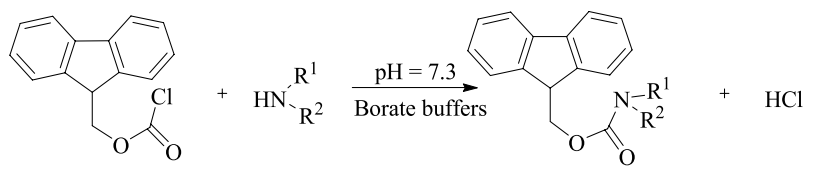

Secondary rection:

FMOC-Cl

FMOC-OH

Figure 3. The reaction of amines with 9-fluorenilmetil-cloroformiato (FMOC-Cl).

the FMOC reacts specifically and rapidly with primary and secondary amines, such as ETM (Figure 3). Furthermore, fluorometric detection has the advantage of being easily implementable in a routine laboratory.

The selectivity of the method was studied by spiking standard ETM solutions with other aminoglycoside antibiotics (tobramycin, netilmicin, kanamycin and gentamicin). The spiked plasma was treated and analyzed as described previously. No chromatographic interference from these drugs was observed. This indicates that the proposed method is specific and feasible for the analysis of ETM in plasma for therapeutic drug monitoring.

\section{Optimization of the reactions}

ETM react with FMOC-Cl under alkaline conditions to form amino derivatives. In addition, FMOC-Cl undergoes hydrolysis to produce FMOC-OH. These reactions are shown in Figure $3 .^{30}$ The derivatization and hydrolysis reactions are influenced by factors, such as $\mathrm{pH}$, the FMOC-Cl concentration and volume, addition sequence of reagents, temperature and reaction time. The effect of these parameters was studied by the batch method using HPLC. The results were shown in Figure 4.
The buffer was used to keep the drugs in dissociative form in order to retain their nucleophilic character. The influence of $\mathrm{pH}$ on the ETM absorbable intensity of the peak area (A) was investigated. In this paper, borate buffer solution was selected to control the $\mathrm{pH}$ of analytical system. The effect of the buffer $\mathrm{pH}$ was investigated in the $\mathrm{pH}$ range from 6.5 to 8.5 . For $\mathrm{pH}>7.5$, the hydrolysis of FMOC-Cl is considerably higher than at lower $\mathrm{pH}$ values. For $\mathrm{pH}<7$ the derivatization time for ETM was too long. Thus $\mathrm{pH}$ 7.0-7.5 was chosen for derivatization and a borate buffer was used to maintain this constant $\mathrm{pH}$. The suitable amount of buffer solution for determination ETM was 30-100 $\mu \mathrm{L}$. The optimum content of buffer solution for the determination of ETM was $50 \mu \mathrm{L}$.

As the hydrolysis of FMOC-Cl depends on its concentration, measurements were made keeping its initial concentration constant and varying the ETM concentration. The effect of FMOC-Cl concentration was studied over a range of 1.93-38.65 $\mu \mathrm{g} \mathrm{mL}^{-1}$. When dosage of the FMOC-Cl is lower than $10.05 \mu \mathrm{g} \mathrm{mL}^{-1}$, the reaction is incomplete, however, when dosage of the FMOC-Cl is higher more than $19.32 \mu \mathrm{g} \mathrm{mL}{ }^{-1}$, superfluous FMOC-Cl would hydrolyze and the hydrolyzing product of FMOC-Cl can disturb other peaks. So, the results showed that the optimum concentration amount of FMOC-Cl was $10.05 \mu \mathrm{g} \mathrm{mL}{ }^{-1}$ for determination of ETM (Figure $4 \mathrm{~b}$ )

It was important to maintain the volume of the FMOC-Cl solution $\left(\mathrm{V}_{1}\right)$ in reaction mixture. When the total solution volume $\left(\mathrm{V}_{2}\right)$ was fixed, the ratio of $\mathrm{V}_{1} / \mathrm{V}_{2}$ was varied from $1 / 8$ to $2 / 3$ and the ratio of $1 / 3$ was found to be the optimum.

Adding sequence was investigated. The experiments indicated that the addition sequence of reagents affected the peak area (A), and the order of plasma, ETM, NMC, buffer solution and FMOC-Cl was the best. 

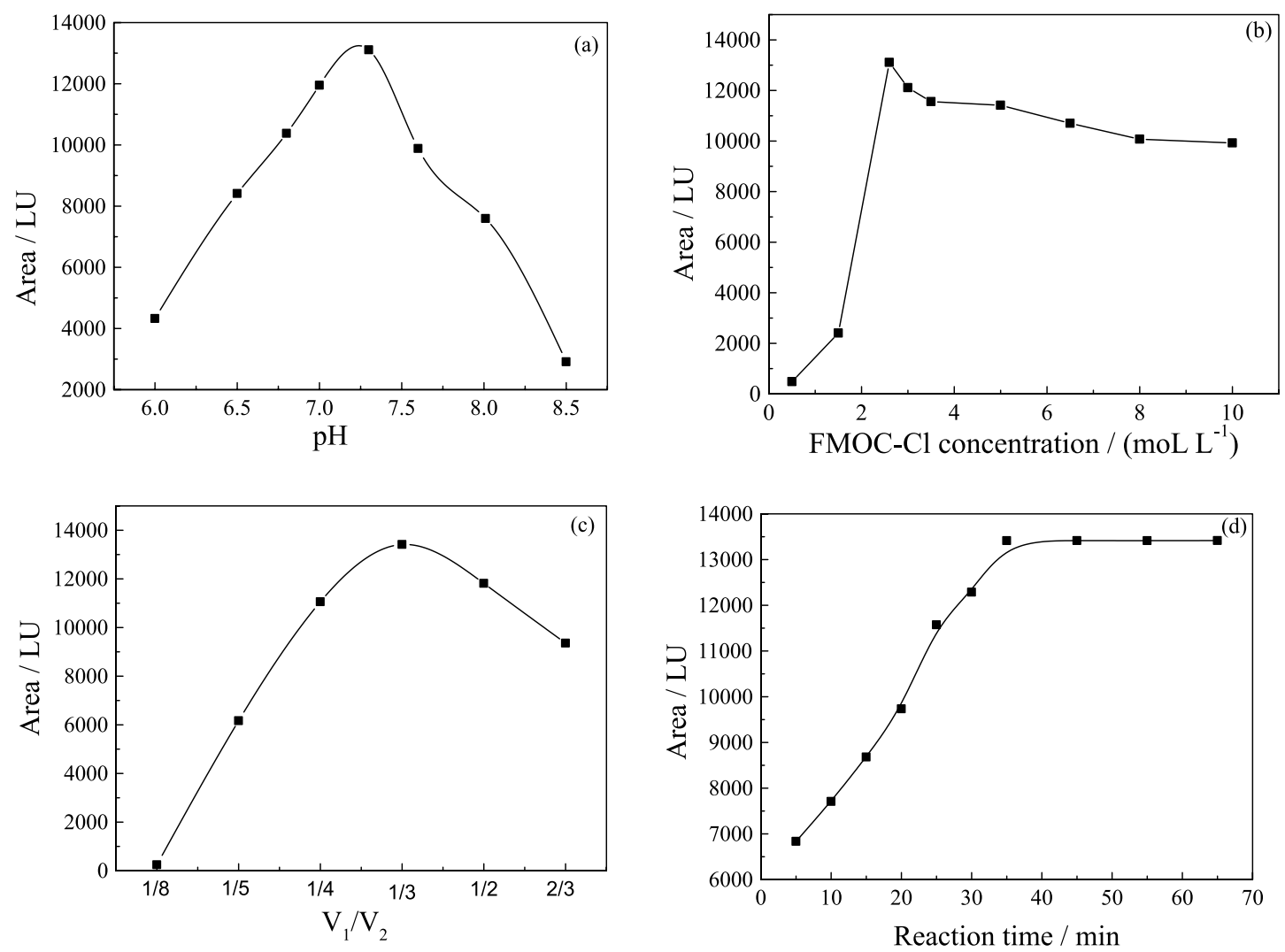

Figure 4. Condition influence for the reaction of ETM with FMOC-Cl: (a) pH influence, (b) FMOC-Cl concentration influence, (c) FMOC-Cl volume influence and (d) time course influence.

The effect of temperature was studied over a range of $15-40{ }^{\circ} \mathrm{C}$, and the results showed that the optimum temperature was kept at ambient temperature (about $25^{\circ} \mathrm{C}$ ) for determination of ETM.

Under the optimum condition, the effect of reaction time on the peak area (A) was investigated. The results showed that the peak area (A) reached a maximum at 35 min after all the reagents added. So in this study, the peak area (A) was recorded after $35 \mathrm{~min}$ in order to make ETM, NMC and FMOC-Cl interacted completely.

\section{Sensitivity and linearity}

The standard calibration curves were linear over the concentration ranges of $0.038-9.69 \mu \mathrm{g} \mathrm{mL} \mathrm{m}^{-1}$. The linear regression equation was obtained as follows: $\mathrm{y}=1.0175 \mathrm{x}$ $+0.0982, r=0.9994$; where $y$ is the peak area ratio of the derived ETM to derived internal standard, $x$ represents concentration ratio of ETM to the internal standard and $r$ is the correlation coefficient. The data indicate good linearity of the proposed method. The limit of detection (LOD) was investigated when the peak height was three times more than the background noise. The lower limit of quantification (LLOQ) was defined as the lowest concentration on the calibration curve $(\mathrm{S} / \mathrm{N}=10) \cdot{ }^{35}$ The detection limit of ETM was $0.01 \mu \mathrm{g} \mathrm{mL}^{-1}$ and LLOQ of ETM was $0.02 \mu \mathrm{g} \mathrm{mL}^{-1}$ for the determination of ETM in rat plasma.

\section{Precision, accuracy, recovery and stability}

Table 1 summarizes the intra- and inter-day precision and accuracy for ETM from QC samples. In this assay, the intra-batch and inter-batch precisions were less than 5.0\% for the drug at the three concentrations tested. These data suggested that the method were accurate and reproducible for the determination of ETM in rat plasma. The relative recoveries of ETM, at concentrations of $0.15,3.64$ and $7.27 \mu \mathrm{g} \mathrm{mL}^{-1}$ were $97.8 \pm 3.8,100.0 \pm 2.5$ and $99.8 \pm 4.8 \%$, respectively (Table 2). The relative recovery of the internal standard was determined at the concentration used in the assay procedure and was found $95.6 \pm 4.6 \%$. The plasma samples were assayed under three different conditions to assess the stability of ETM in plasma samples. All stabilities were assayed at three concentration levels (low, medium, high). In short-term stability test, samples were stored in refrigerator $\left(4{ }^{\circ} \mathrm{C}\right)$ for $0-24 \mathrm{~h}$, the assay was performed at $0,2,4,8,12$ and $24 \mathrm{~h}$, and the results showed 98.0-102.1\% of initial content of ETM was recovered. 
Long-term stability was studied by assaying samples after $1,3,5,8$ and 10 days of storage $\left(-20{ }^{\circ} \mathrm{C}\right), 97.7-103.6 \%$ of initial content of ETM was recovered. The stability of freeze-thaw cycles was done over two cycles at $-20^{\circ} \mathrm{C}$, 95.2-105.9\% of initial content of ETM was detected. The previous stability tests demonstrated that those analytes were stable under these conditions.

Table 1. Intra- and inter-day accuracy and precision of ETM determination at three concentration levels $(n=5)$

\begin{tabular}{lcc}
\hline $\begin{array}{l}\text { Added } /\left(\mu \mathrm{g} \mathrm{mL}{ }^{-1}\right) \\
\text { Intra-day }\end{array}$ & R. S. D / $\%$ & Accuracy RE / \% \\
\hline 0.15 & 3.9 & -2.1 \\
3.64 & 1.5 & 1.0 \\
7.27 & 2.2 & -2.5 \\
\hline Inter-day & & \\
\hline 0.15 & 4.6 & -4.1 \\
3.64 & 2.3 & 1.7 \\
7.27 & 2.1 & -2.0 \\
\hline
\end{tabular}

Table 2. The relative recovery of ETM from plasma $(n=3)$

\begin{tabular}{lccc}
\hline \multirow{2}{*}{ Sample } & \multicolumn{2}{c}{ Concentration / $\left(\mu \mathrm{g} \mathrm{mL}^{-1}\right)$} & Recovery / \% \\
& Added & Found (mean \pm S.D. $)$ & \\
\hline LQC & 0.15 & $0.146 \pm 0.01$ & 97.8 \\
MQC & 3.64 & $3.64 \pm 0.04$ & 100.0 \\
HQC & 7.27 & $7.25 \pm 0.01$ & 99.8 \\
\hline
\end{tabular}

Application of the analytical method in pharmacokinetic studies

This validated method was applied in monitoring the plasma concentration of ETM in rats that were administered an intravenous injection dose of $30 \mathrm{mg} \mathrm{kg}^{-1}$. The main pharmacokinetic parameters of ETM, calculated by noncompartmental analysis, were as follow: the elimination half-life $\left(\mathrm{T}_{1 / 2}\right)$ was $1.87 \pm 0.28 \mathrm{~h}$, elimination rate constant (K) was $0.19 \pm 0.03 \mathrm{~h}^{-1}$, the area under the curve $\left(\mathrm{AUC}_{0-\infty}\right)$ was $54.41 \pm 8.32 \mu \mathrm{g} \mathrm{h} \mathrm{mL}{ }^{-1}$, the volume of distribution $\left(\mathrm{V}_{\mathrm{d}}\right)$ was $2.89 \pm 0.45 \mathrm{~L}$, the initial plasma concentration $\left(\mathrm{C}_{0}\right)$ was $10.38 \pm 1.64 \mu \mathrm{g} \mathrm{mL} \mathrm{m}^{-1}$ and total clearance $\left(\mathrm{CL}_{\text {tot }}\right)$ was $0.55 \mathrm{~mL} \mathrm{~h}^{-1}$. Therefore, this method had adequate sensitivity for the determination of ETM in rat plasma. The pharmacokinetic parameters derived from these data are presented in Table 3. The mean ( \pm S.D.) plasma concentration-time profile of ETM in rats $(n=5)$ is shown in Figure 5. By monitoring the plasma concentration of ETM, it was found that it decreased gradually, and ETM was primarily metabolized via original shape and almost completely finished in $12 \mathrm{~h}$.
Table 3. Pharmacokinetic characteristics of ETM in the plasma of healthy rats $(\mathrm{n}=5)$, that were administered a intravenous injection dose of $30 \mathrm{mg} \mathrm{kg}^{-1}$

\begin{tabular}{lc}
\hline ETM pharmacokinetic parameter values (mean \pm S.D. $)^{\mathrm{a}}$ \\
\hline $\mathrm{AUC}_{0-\infty} /\left(\mu \mathrm{g} \mathrm{h} \mathrm{mL}{ }^{-1}\right)$ & $54.41 \pm 8.05$ \\
$\mathrm{CL}_{\text {tot }} /\left(\mathrm{mL} \mathrm{h}^{-1}\right)$ & $0.55 \pm 0.08$ \\
$\mathrm{~V}_{\mathrm{d}} / \mathrm{L}$ & $2.89 \pm 0.45$ \\
$\mathrm{~K}_{10} / \mathrm{h}^{-1}$ & $0.19 \pm 0.03$ \\
$\mathrm{t}_{1 / 2} / \mathrm{h}$ & $6.87 \pm 1.48$ \\
\hline aEach value represents the mean $+\mathrm{S} . \mathrm{D}$. of five experiments.
\end{tabular}

${ }^{a}$ Each value represents the mean \pm S.D. of five experiments.

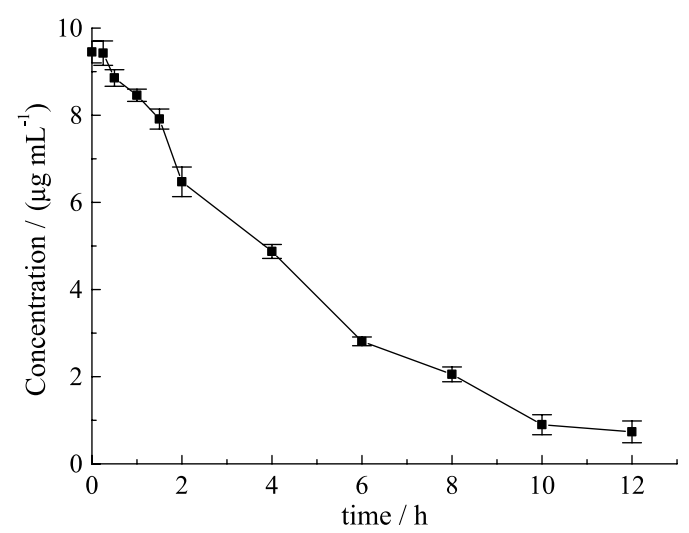

Figure 5. The average plasma concentration-time profile of the ETM after intravenous administration of $30 \mathrm{mg} \mathrm{kg}^{-1}$ to five Wistar rats.

\section{Conclusion}

In conclusion, the current method appeared to be precise, rapid and sensitive for the determination of ETM in rat plasma. In this method, the reaction of the drug with $\mathrm{FMOC}-\mathrm{Cl}$ is rapid and stable derivative is produced, the procedure is easy to perform. Besides, our method involves small sample volume $(50 \mu \mathrm{L})$, short time of analysis (13 min) and a simple sample extraction and clean-up as compared to the previously published methods. Further studies are ongoing in our laboratory to characterize the transporters involved and their role in absorption of ETM.

\section{Acknowledgments}

The authors are grateful to the support of the Key Laboratory of Electromagnetic Radiation Protection, Third Military Medical University.

\section{References}

1. Xi, L. L.; Wu, G. F.; Zhu, Y.; J. Chromatogr. A 2006, 1115, 202.

2. Adams, E.; Pueling, D.; Rafiee, M.; Hoogmartens, J.; J. Chromatogr. A 1998, 812, 151.

3. Liao,Y. A.; Dai, S. H.; Chin. J. Antibiotics 1995, 20, 198. 
4. Šoltés, L.; Biomed. Chromatogr. 1999, 13, 3.

5. Shawar, R. M.; MacLeod, D. L.; Garber, R. L.; Burns, J. L.; Stapp, J. R.; Clausen, C. R.; Tanaka, S. K.; Antimicrob. Agents Chemother. 1999, 43, 2877.

6. Yi, A. R.; Liu, Z. F.; Liu, S. P; Hu, X. L.; J. Lumin. 2009, 24, 23.

7. Sabath, L. D.; Casey, J. I.; Ruch, P. A.; Stumpf, L. L.; Finland, M.; J. Lab. Clin. Med. 1971, 78, 457.

8. Andrews, J. M.; Wise, R.; J. Antimicrob. Chemther. 1984, 14, 509.

9. Bromn, S. A.; Newkirk, D. R.; Hualer, R. P.; Smith, G. G.; Sugimoto, K. J.; Assoc. Off. Anal. Chem. 1990, 73, 479.

10. Flurer, C. L.; Wolnik, K. A.; J. Chromatogr. A 1994, 663, 259.

11. Calcara, M.; Enea, V.; Pricoco, A.; Miano, F.; J. Pharm. Biomed. Anal. 2005, 38, 344.

12. Bhogte, C. P; Patravale, V. B.; Devarajan, P. V.; J. Chromatogr. B: Anal. Technol. Biomed. Life Sci. 1997, 694, 443.

13. Mayhew, J.; Gorbach, S.; J. Chromatogr. 1978, 151, 133.

14. Vogel, R.; Drfillipo, K.; Reif, V.; J. Pharm. Biomed. Anal. 2001, 24, 405.

15. State Pharmacopoeia Committee.; The Chinese Pharmacopeia, Chemical Industry Publishing House: Bei Jing, 2005, vol. 2, p. 740.

16. Kaine, L. A.; Wolnik, K. A.; J. Chromatogr. 1994, 674, 255.

17. Adams, E.; Liu, L.; Dierick, E.; Guyomard, S.; Nabet, P.; Rico, S.; Louis, P.; Roets, E.; Hoogmartens, J.; J. Pharm. Biomed. Anal. 1998, 17, 757.

18. Mclaughlin, L. G.; Henion, J. D.; J. Chromatogr. 1992, 591, 195. 19. Pastore, P.; Gallina, A.; Magno, F.; Analyst 2000, 125, 1955.

20. McLaughlin, L. G.; Henion, J. D.; Kijak, P.; J. Biol. Mass Spectrom. 1994, 23, 417.
21. Hu, P.; Chess, E. K.; Brynjelsen, S.; Jakubowski, G.; Melchert, J.; Hammond, A.; J. Am. Soc. Mass Spectrom. 2000, 11, 200.

22. Loffler, D.; Ternes, T. A.; J. Chromatogr. A 2003, 1000, 583.

23. Shriram, M.; Pathak, A.; Kumar, R.; Musmade, P.; Udupa, N.; Talanta 2008, 76, 338.

24. Mashat, M.; Chrystyn, H.; Clark, B. J.; Assi, K. H.; J. Chromatogr. B: Anal. Technol. Biomed. Life Sci. 2008, 869, 59.

25. Shi, H. Q.; Wang. J.; Chin. J. Pharm. 2003, 34, 290.

26. Kim, B. H.; Kim, Y. K.; Ok, L. H.; J. Chromatogr. B: Anal. Technol. Biomed. Life Sci. 2001, 752, 173.

27. Kim,B. H.; Lee, C.; Lee, H. J.; Ok, J. H.; Biomed. Chromatogr. 2003, 17, 396.

28. Fishermen, N.; Soback, S.; Clin. Chem. 2000, 46, 837.

29. Zhou, M. J; Wei, G. L; Liu, Y. P; Sun, Y. M; Xiao, S. H; Lu, L.; Liu, C. X; Zhong, D. F; J. Chromatogr. B: Anal. Technol. Biomed. Life Sci. 2003, 798, 43.

30. Liu, Z.; Sha, Y.; Huang, T.; Yang, B.; Duan, G. L.; J. Chromatogr. B: Anal. Technol. Biomed. Life Sci. 2005, 828, 2.

31. Peng, W.; Jackson, G. G.; Chiou, W. L.; Antimicrob. Agents Chemother. 1977, 12, 707.

32. Suhren, G.; Knappstein, K.; Analyst 1998, 123, 2797.

33. Xi, L. L.; Wu, G. F.; Zhu, Y.; J. Chromatogr. A 2006, 1115, 202.

34. Wang, J.; Wang, D. D.; Ni, K. Y.; Hu, X. J.; J. Liq. Chromatogr. Relat. Technol. 2007, 30, 1001.

35. Yuan, J. B.; Nie, L. H.; Zeng, D. Y.; Luo, X. B.; Tang, F.; Ding, L.; Liu, Q.; Guo, M. L.; Yao, S. Z.; Talanta 2007, 73, 644.

Submitted: April 17, 2010

Published online: March 1, 2011 